\title{
Circular
}

OF THE

\section{BUREAU OF STANDARDS}

S. W. STRATTON, DIRECTOR

No. 13

STANDARD SPECIFICATIONS FOR LARGE INCANDESCENT ELECTRIC LAMPS

[Tungsten and Carbon]

[9th ed., July. 30, 1921]

[Superseding 8th ed., issued Apr. 13, 1918]

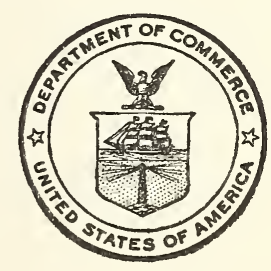

PRICE 5 CENTS

Sold only by the Superintendent of Documents, Government Printing Office, Washington, D. C.

WASHINGTON

GOVERNMENT PRINTING OFFICE 


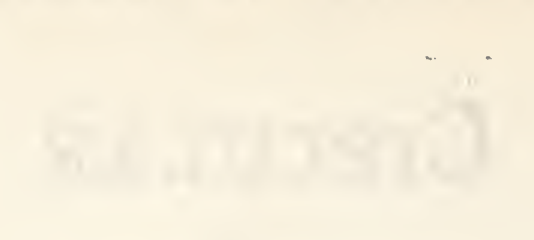

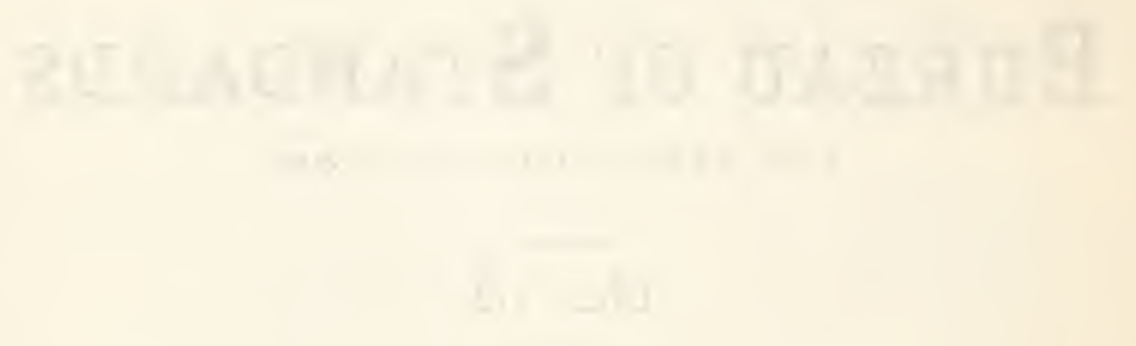

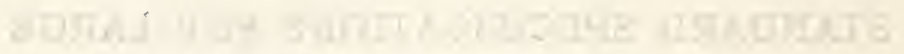

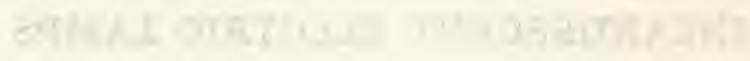

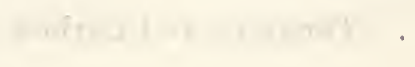

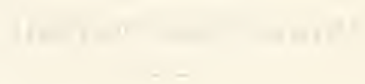

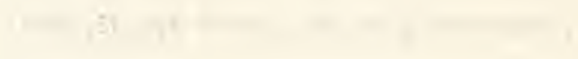




\title{
STANDARD SPECIFICATIONS FOR LARGE INCANDES- CENT ELECTRIC LAMPS
}

\author{
[Tungsten and Carbon]
}

\section{CONTENTS}

Introductory statement.

PART 1.-STANDARD SPECIFICATIONS FOR LARGE TUNGSTEN FILAMENT INCANDESCENT ELECTRIC LAMPS

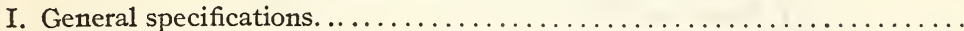

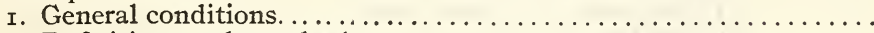

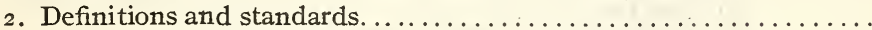

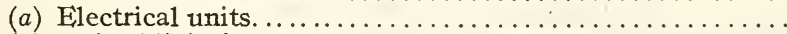

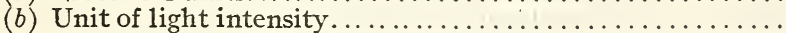

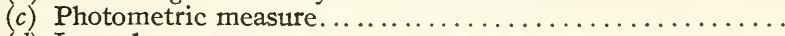

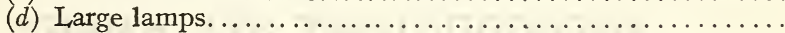

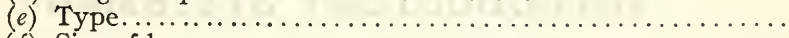

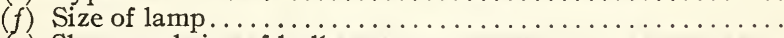

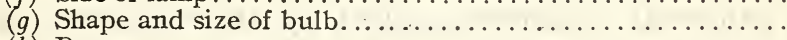

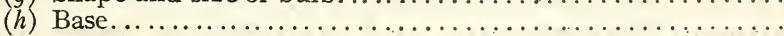

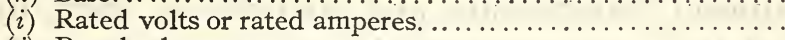

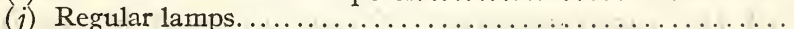

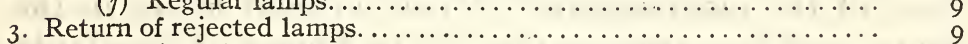

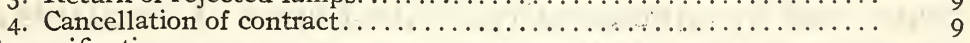

II. Test specifications. . . . . . . .

I. Mechanical and physical inspection test. ............... Io

(a) Selection of lamps for mechanical and physical inspection

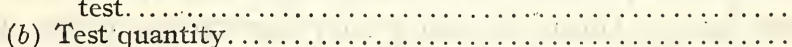

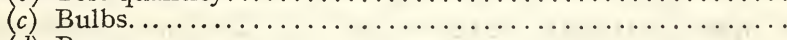

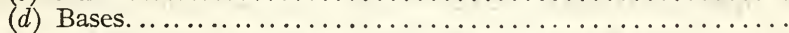

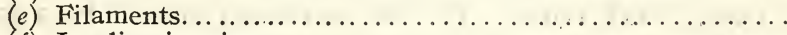

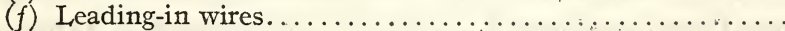

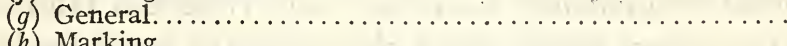

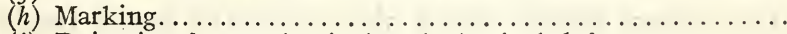

(i) Rejection for mechanical and physical defects.........

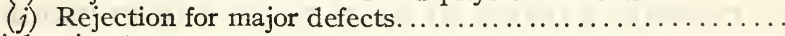

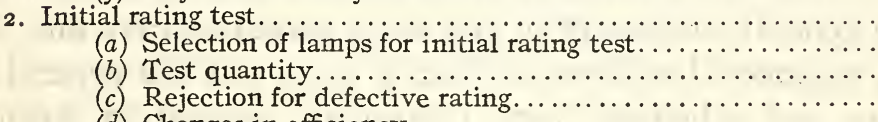

(d) Changes in efficiency.

3. Life performance test.

(a) Selection and test quantity of lamps for life performance

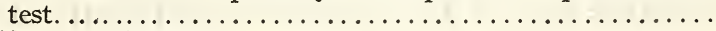

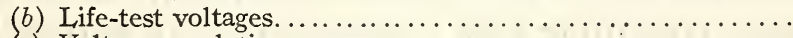

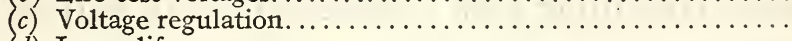

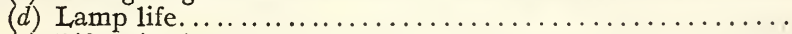

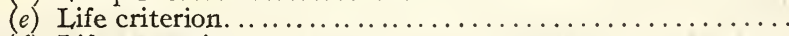

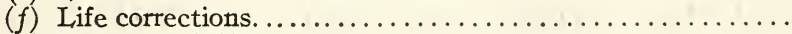

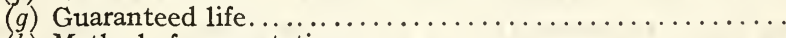

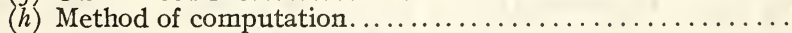

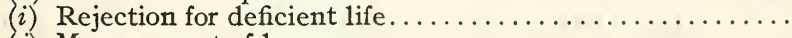

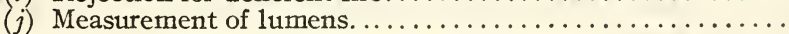

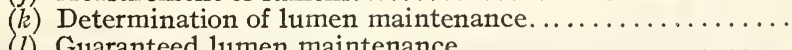

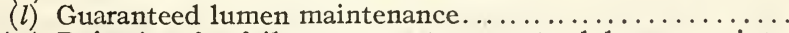

$(m)$ Rejection for failure to meet guaranteed lumen mainte-

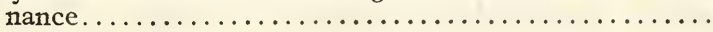

III. Tables of tolerances and criteria . . . . . . . . . .

IV. Standard schedules of commercial ratings. . . . . . . . . 


\section{PART 2.-STANDARD SPECIFICATIONS FOR LARGE CARBON FILAMENT} INCANDESCENT ELECTRIC LAMPS

I. General specifications. ............................... I8

I. General conditions............................. I8

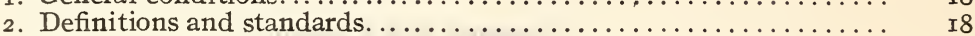

3. Return of rejected lamps............................ I8

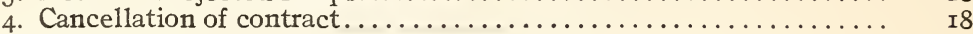

II. Test specifications. . . . . . . . . . . . . . . . . . . . . . .

I. Mechanical and physical inspection test................ I9

2. Initial rating test. . . . . . . . . . . . . . .

3. Life performance test............................. I9

(a) Selection and test quantity of lamps for life performance

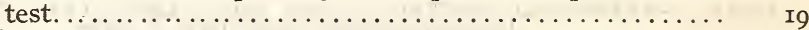

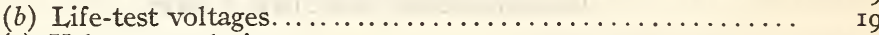

(c) Voltage regulation................... I9

(d) Candlepower measurements.......................... I8

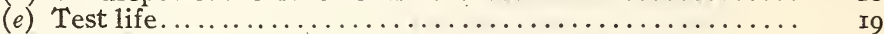

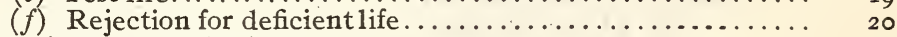

III. Tables of requirements and tolerances $\ldots \ldots \ldots \ldots \ldots \ldots \ldots \ldots \ldots \ldots \ldots . . . \ldots$

\section{INTRODUCTORY STATEMENT}

An informal conference called by the engineers of the various Government departments, and attended by them, by representatives of the manufacturers of incandescent lamps in the United States, and by representatives of the Bureau of Standards and the Electrical Testing Laboratories, was held in Washington, February 25 to 27,1907 , at which specifications for electric incandescent lamps, then including only the carbon class, were adopted. These specifications were revised at further conferences held in 1908, 1909, and 1910. In the revision made in 1909, schedules for metallized carbon, tantalum, and tungsten lamps were added. In I9Io carbon lamps were placed on the same basis as the other classes, namely, a rating in watts instead of in candlepower.

No general conference of the lamp manufacturers and Government engineers has been held since I9ro, but the general specifications and schedules were thoroughly revised in April, I9I2, after informal conferences between representatives of the Bureau of Standards and of the various departments of the Government, and after consulting with representatives of various lamp manufacturers.

Four further revisions have been made by the Bureau after consulting with representative manufacturers. These revisions were made in I9I3, I9I5, I9I 7 , and the latest, for the present (ninth) edition, in $192 \mathrm{I}$.

In this edition noteworthy changes have been made in the test procedure specified for tungsten lamps. The most notable of these changes is the abandonment of the long-established provision that the life of test lamps shall be considered as ended when 
the candlepower has fallen to 80 per cent of the initial value. The specification of such an end point is convenient and reasonable in the testing of carbon lamps, because those lamps will often burn for a long period after they have become so blackened that they should not be continued in use. In tungsten lamps, however, means have been found to prevent excessive blackening of the bulbs, so that the lamps normally burn out before their efficiency has fallen enough to justify replacing them. The new tests will therefore be based on the total life to the time of burn out, thus conforming more nearly to actual practice in the use of lamps.

The performance of the lamp throughout its life will also be taken into account through two new provisions. One of these is the evaluation of life-test results on the basis of average efficiency throughout life, instead of the initial efficiency; the other is a requirement that the average light flux during the life of the lamp must not fall below a specified percentage of the initial flux.

Another new feature is the establishment of tolerances to allow for possible variations in test results arising from the fact that small numbers of test samples may not represent fairly the average quality of the lamps from which they are selected. Special provision is also made for the rejection of lamps when a considerable number are found to show vital defects on the initial inspection.

On account of the desirability of standardizing a small number of voltage ratings, the tungsten lamp schedules recognize specifically only the 5 volt steps in the I IO-I 20 volt range and Io volt steps in the $220-250$ volt range. It is understood that, for the present, lamps of other voltages within the usual range will be furnished under the same specifications, but users will ultimately find it advantageous to bring their circuits to one of the standard voltages.

Tests under these new specifications are intended to give a more complete indication of the performance of lamps than was obtained under the former specifications, and thus to discriminate more exactly between types of lamps. In the first application of the new specifications it has, however, been deemed wise to make the requirements moderate. The numerical values in the tables of requirements are based on extensive studies of the performance of lamps in tests made by various manufacturers as well as by the Bureau of Standards. It is believed that they have been so adjusted that the change in specifications will involve no injustice either to lamp manufacturers or to purchasers.

The earlier specifications included in a single set of schedules both technical requirements and practical ratings for lamps, 
whereas the trend of recent practice has been toward separation into two distinct sections. One of these would describe in detail the tests and methods by which the intrinsic merit of lamps is to be determined, and would specify the criteria to be met, while the other would cover those details of rating of the lamps which affect their suitability for use under the average commercial conditions met in practice. For example, lamps of a given size and kind may fairly be compared only on the basis of tests at the same efficiency, but the most economical efficiency for actual operation must depend on several factors, including especially costs of lamps and of energy. The part of the specifications dealing with intrinsic quality would be the same for all types of lamps, while the life and corresponding efficiency ratings in the other part might be adjusted to suit the conditions of the general class of service for which the lamp is intended. On account of limitations on the time within which this edition has had to be prepared, this separation of elements has not been completely and logically carried out. Sections I, II, and III, Part I, however, constitute the major part of the quality specifications, while Section IV is largely commercial ratings, as is indicated by its title.

The carbon-lamp schedule has been retained because these lamps still properly find a considerable application, particularly in service where the renewal cost of tungsten filament lamps would be excessive on account of an unusual amount of theft or breakage. For carbon lamps the specifications are practically unchanged from those given in previous editions of this circular. They are therefore different in many respects from the new requirements for tungsten lamps. On account of this difference the specifications for the two classes of lamps have been separated in this edition.

Criticisms and suggestions concerning these specifications and lamp ratings are invited from both manufacturers and users of lamps. All such suggestions will be carefully considered when the specifications are again revised.

These specifications have been prepared primarily for the use of the departments of the Government in purchasing incandescent lamps, but it seems desirable, on account of the thoroughness with which the subject has been studied and discussed, that the specifications should be available to the general public. In circulating them, however, the Bureau desires to call attention to the necessity of extreme caution in the application of the tests described. Only 
those thoroughly instructed in the art of lamp manufacture and in the science of photometry should undertake to determine upon the acceptability of lamps under the terms of these specifications.

\section{PART 1.-STANDARD SPECIFICATIONS FOR LARGE TUNGSTEN FILAMENT INCANDESCENT ELEC- TRIC LAMPS}

Complete specifications for the purchase of large tungsten filament incandescent lamps consist of the following sections:

I. General Specifications

II. Test Specifications

III. Tables of Tolerances and Criteria

IV. Standard Schedules of Commercial Ratings

Sections I, II, and III describe in detail the tests and methods that may be employed for the determination of the inherent quality of the lamps. Section IV consists largely of dimensions and of ratings which affect the economy of operation of lamps of a given quality. The values given in Section IV of this circular are considered at the present time to represent good practice under conditions of use most commonly prevailing in the United States, and are therefore made a part of the specifications under which the United States Government purchases such lamps

\section{GENERAL SPECIFICATIONS}

\section{GENERAL CONDITIONS}

Incandescent lamps to be furnished under these specifications shall be new lamps.

The full provisions of these specifications shall apply only to lamps specifically mentioned in the tables of tolerances and criteria, and to no other lamps, except by mutual written agreement.

These specifications shall not apply to any frosted, bowl enameled, etched, or colored lamps, or to lamps other than those with the usual clear glass bulbs, unless specifically included by mutual written agreement.

These specifications in so far as they refer exclusively to mechanical and physical characteristics shall apply to any lamps regularly listed in the manufacturer's current schedules.

All tests shall be made in a competent and expert engineering manner at the expense of the purchaser, excepting that when initial tests and inspections are made at the factory, the manu- 
facturer will be required to supply the necessary equipment, assistance, current, and facilities for making such initial tests and inspections. The manufacturer shall have the privilege of witnessing and verifying all tests of its lamps made hereunder, and shall also have the privilege of obtaining copies of the results of the tests of its lamps and of having access to the records of such tests at all reasonable times. Prompt notice of the result of lamp tests will be given the manufacturer.

With the consent of the manufacturer, the method of test procedure may be modified in any particular whenever such modification is desirable to secure test results in a more practicable, representative, and accurate manner.

\section{DEFINITIONS AND STANDARDS}

(a) Electrical Units.-The values of the electrical units in these specifications are those which have been in force since January I, I9II.

(b) Unit of Light Intensity.-The unit of light intensity shall be the international candle as maintained by the Bureau of Standards at Washington, D. C.

(c) Photometric Measure.-The basis of photometric measure for all lamps shall be total flux expressed in lumens, but, if desired, the equivalent luminous intensity expressed in spherical candles may be used. In the case of vacuum lamps the initial lumens or spherical candles may be calculated from measured values of the mean horizontal candlepower by the use of initial spherical reduction factors given in the Standard Schedules of Commercial Ratings, in which case allowance shall be made for such changes as may occur in spherical reduction factors during life performance test of all lamps.

For lamps having filaments giving an initial ratio of mean spherical to mean horizontal candlepower different from the values given in the tables the horizontal candlepower measurements shall be corrected by an initial spherical reduction factor determined by the Bureau of Standards or other authority mutually agreed upon, and the life performance values shall be equivalent to those given in the tables.

(d) Large Lamps.-Lamps are classified under two styleslarge and miniature. "Large lamps" designates broadly lamps regularly fitted with other than miniature bases. All lamps covered by these specifications are large lamps. 
(e) Type.-The word "type" is used to distinguish between lamps which differ in general construction or are designed for different classes of service.

(f) Size of Lamp.-The size of incandescent lamps is expressed in rated watts or rated lumens.

(g) Shape and Size of Bulb.-The shape of a bulb is designated by a letter; $S$ indicates it is straight side; $G$ indicates round (globular); PS indicates pear shape; $T$ indicates tubular. The size of bulb is expressed by a number defining the greatest diameter in eighths of an inch (S-I7, straight side bulb, $\frac{17}{8}$ or $21 / 8$ inches greatest diameter; $\mathrm{G}-18 \mathrm{1} / 2$, round bulb, $18 \mathrm{r} / 2$ eighths or $2 \frac{5}{16}$ inches in diameter).

(h) Base.-There are five varieties of bases, miniature screw, candelabra screw, bayonet, medium screw, and mogul screw. Medium and mogul screw bases only are used on lamps covered by these specifications.

(i) Rated Volts or Rated Amperes.-The rated volts or rated amperes of a lamp are the volts or amperes for which the lamp is designed as indicated on the label.

(j) Regular Lamps.-Regular lamps are lamps whose construction conforms to that regarded as standard and are so listed by the manufacturer. Only large regular lamps are covered by these specifications.

\section{RETURN OF REJECTED LAMPS}

Lamps which have not been used and are rejected under the terms of these specifications may be returned to the manufacturer at his expense, and no payment made therefor. All lamps placed in service shall be considered as accepted.

\section{CANCELLATION OF CONTRACT}

A contract for lamps furnished under these specifications may be canceled in the event that the total quantity of lamps represented on life performance tests exceeds in value 25 per cent of the face value of the contract and is represented on life performance test by at least 50 lamps and is rejectable as an aggregate quantity under Life Performance Test, paragraphs $(i)$ or $(m)$, or in the event that the total quantity of lamps is represented by not less than 200 lamps completed on the life performance test and is rejectable as an aggregate quantity under these specifications. $54128^{\circ}-21-2$ 


\section{TEST SPECIFICATIONS}

\section{MECHANICAL AND PHYSICAL INSPECTION TEST}

(a) Selection of Lamps for Mechanical and. Physical Inspection Test.-From each lot of lamps there shall be selected at random the test quantity for the purpose of determining the mechanical and physical characteristics of the lamps. The manufacturer may present lamps for mechanical and physical inspection test which have not been sufficiently burned or seasoned to have reached stable values of wattage and lumens.

(b) Test Quantity.-The test quantity shall consist of not less than 5 per cent of each lot of lamps of any one type, size, and voltage inspected, and in no case shall be less than ro lamps.

The inspector may select as a lot of lamps to be inspected any individual package, or any group of packages containing lamps of any one type, size, and voltage.

The lamps comprising the test quantity shall be selected proportionately from the several packages composing the lot and shall be known as the inspection test lamps.

(c) Bulbs.-Bulbs shall be uniform in size and shape, clear, clean, and free from flaws and blemishes detrimental to service.

(d) Bases.-Moisture-proof medium or mogul screw bases, fitted with glass insulation, shall be used on all lamps unless otherwise specified, and when bases have extended skirts the latter shall be insulated from the screw shell. The bases shall be firmly and accurately fitted to the bulbs with moisture-proof cement. The shells and skirts of the bases shall be of brass of good quality.

(e) Filaments.-The filaments shall be uniform and free from imperfections, spots, and discolorations detrimental to service.

(f) Leading-in Wires.-Leading-in wires shall be securely attached to the ends of the filaments and shall be securely attached, without excess of solder, to the terminals of the base which make contact with the socket. The threads of the base shall be free from solder.

(g) General.-The lamps shall be well made and free from defects and imperfections which would prevent their meeting satisfactorily the lighting service conditions.

All lamps shall conform to the manufacturer's current standard shapes and sizes of bulbs and forms of filament.

(h) Marking.-One or more labels showing the rating and the manufacturer's name or trade-mark shall be placed on the bulb or the base of each lamp. 
The labels on the lamps shall show the rated watts and volts (or voltage of the circuit upon which a stated number of lamps are to burn in series), or the rated lumens and amperes.

(i) Rejection for Mechanical and Physical Defects. -The test quantity of lamps selected from any lot of lamps shall be inspected for physical defects, and when so inspected, provided that the inspection test is made at the factory, if 20 per cent or more of the test lamps show physical defects incompatible with good workmanship, good service, or with any clause of these specifications, any package or group of packages, or the entire lot of lamps from which the test quantity was selected, may be rejected without further test. If the inspection test is made elsewhere than at the factory, this percentage of defective lamps required for rejection shall be 30 per cent.

(j) Rejection for Major Defects.-Also, when so inspected, if the number of the test lamps that are inoperative, or that would unquestionably give poor service (such defects to be mutually agreed upon), exceeds the quantity indicated in the table below for the number of lamps inspected, any package or group of packages, or the entire lot from which the test quantity was selected, may be rejected without further test.

\begin{tabular}{|c|c|c|}
\hline \multirow{2}{*}{$\begin{array}{l}\text { Total number } \\
\text { of test lamps } \\
\text { inspected }\end{array}$} & \multicolumn{2}{|c|}{ Number of vitally defective lamps required for rejection [see $1(j)$ above] } \\
\hline & $\begin{array}{l}\text { When inspection test is made at the } \\
\text { factory }\end{array}$ & When inspection test is made elsewhere \\
\hline Above $400 \ldots . . .$. & More than 3 per cent of number inspected. & More than 5 per cent of number inspected \\
\hline $400-301$. & More than 10 lamps........ & More than 20 lamps \\
\hline $300-201 .$. & More tioan 7 lamps........ & More than 14 lamps \\
\hline $200-101$ & More than 5 lamps......... & More than 10 lamps \\
\hline $100-51 \ldots .$. & More than 3 lamps........... & More than 6 lamps \\
\hline 50 and less.. & More than 2 lamps............ & More than 4 lamps \\
\hline
\end{tabular}

\section{INITIAL RATING TEST}

(a) Selection of Lamps for Initial Rating Test.-From each lot of lamps there shall be selected at random the test quantity for the purpose of making the initial rating test, or the test may be made upon the same lamps that were selected for the mechanical and physical inspection test. Lamps may be presented for initial rating test that have not been sufficiently burned or seasoned to have reached stable values of wattage and lumens, but such of these lamps as are selected for the initial rating test must be properly seasoned. 
(b) Test Quantity.-The test quantity shall consist of not less than 5 per cent of each lot of lamps of any one type, size, and voltage inspected, and in no case shall be less than ro lamps.

The inspector may select as a lot of lamps to be subjected to the initial rating test any individual package, or any group of packages containing lamps of any one type, size, and voltage.

The lamps comprising the test quantity shall be selected proportionately from the several packages composing the lot, and shall be known as the rating test lamps.

(c) Rejection for Defective Rating.-Iamps shall be tested at rated volts, amperes, or lumens. When tested at the factory, any package or lot may be rejected without further test in the event of 20 per cent or more of the test lamps departing from the manufacturer's current standard initial rating by more than the initial rating tolerances given in the Tables of Tolerances and Criteria. When tested elsewhere than at the factory, this percentage required for rejection shall be 30 per cent.

(d) Changes in Efficiency.-For the purpose of maintaining the rated life given in the Standard Schedules of Commercial Ratings the initial rated lumens per watt (and therewith, proportionately, the mean lumens per watt) of any size of lamps may, upon notice from the manufacturer, be changed, but not numerically decreased by more than 4 per cent, and thereupon the manufacturer may issue new schedules. The initial rating tolerance specified shall apply to the lamps at the changed rated lumens per watt.

\section{IIFE PERFORMANCE TEST}

(a) Selection and Test Quantity of Lamps for Life Performance Test.-For the purpose of selecting lamps for life performance test, packages containing less than roo lamps of any one type, size, and voltage may be grouped to aggregate not more than 250 lamps. From such groups and from standard packages containing roo or more lamps each, at least one sample shall be selected from the lot of lamps selected for initial rating test which approximates most closely to the average of this test quantity. The lamp thus selected will be designated as the lifetest lamp. A second or duplicate lamp may be reserved to replace this life-test lamp, in case of accidental breakage or damage during test. On all tests for determining life performance, each package or group of packages which will be affected by the results of test shall have at least one lamp on such test. 
(b) Life-Test Voltages.-Life-test lamps shall be operated on the test rack at voltages (or currents) corresponding either to-

The initial rated lumens per watt as given in the Standard Schedules of Commercial Ratings, or

The initial test lumens per watt as given in the Tables of Tolerances and Criteria, or

Any special efficiency mutually agreed upon.

Operation at approximately the voltages indicated is sanctioned, provided proper life corrections are made.

(c) Voltage Regulation.-Accurate recording voltmeter records shall be obtained during the test to show the variation of the voltage on the circuit.

Variations of voltage are not to exceed one-quarter of I per cent above and below the test voltage.

(d) Lamp Life.-The life of a lamp is the number of hours life of the lamp to burn out.

Lamps broken in handling or when current is not on them shall not be counted to reduce the average lamp life.

In case any life-test lamps (and their duplicates) are broken or damaged before the test is completed, the average life of all lamps of the same type, size and voltage, tested under the same contract shall be assigned to the package or group of packages represented by such broken or damaged life-test lamps.

Any lamp which shows a relatively sudden and marked decline in light output shall be considered to have terminated its life when its light output passes below 60 per cent of its initial light output.

(e) Life Criterion.-The criterion of inherent quality of a group of lamps is the number of hours life to burn out, as determined in accordance with these specifications, at any stipulated mean lumens per watt throughout life. Criteria for the commonly used lamps are given in the Tables of Tolerances and Criteria.

The conformity of a group of lamps with the life criterion is determined by correcting the average life of the group from the mean efficiency at which the lamps operate during the life performance test to the mean efficiency upon which the life criterion is based.

The life criteria are given only to enable a convenient and direct comparison to be made at all times of the inherent quality of lamps.

(f) Life Corrections.-All life corrections from one efficiency to another are to be made in accordance with life-efficiency relations 
mutually agreed upon or as determined by the Bureau of Standards at Washington, D. C.

(g) Guaranteed Life.-The guaranteed life given in the Standard Schedules of Commercial Ratings is the number of hours life to burn out, for a group of lamps, as determined in accordance with these specifications, at the mean lumens per watt throughout life specified in those Schedules, except as modified by paragraph (i) below.

The conformity of a group of lamps with the life guaranty is determined by correcting the average life of the group from the mean efficiency at which the lamps operate during the life performance test to the mean efficiency upon which the guaranteed life is based.

(h) Method of Computaition.-The individual lamps shall be tested at voltages (or currents) corresponding to equal initial efficiencies and the average number of hours life to burn out determined for the group of lamps. The mean efficiency throughout life of any group of lamps shall be determined as the quotient of the total lumen-hours and watt-hours of the group when so tested. The average life obtained on test shall be corrected from the computed mean efficiency throughout life to the mean lumens per watt specified in the Standard Schedule of Commercial Ratings.

Obtaining the mean efficiency as the quotient outlined in the preceding paragraph is identical with a determination of it as the average of the mean efficiencies throughout life of the individual lamps, the mean efficiency of each lamp being weighted in proportion to the life of the lamp.

(i) Rejection for Deficient Life.-Any group of lamps, provided such group is represented by at least five lamps on life performance test, may be rejected if the average hours life of the group, when corrected to the mean lumens per watt throughout life specified in the Standard Schedule of Commerical Ratings [as modified by Article 2, Initial Rating Test, paragraph (d) Changes in Efficiency], falls below the guaranteed life by more than the life tolerance specified below for the number of test lamps averaged. 
Life Tolerances $a$

\begin{tabular}{|c|c|c|c|c|c|}
\hline $\begin{array}{l}\text { Number of lamps } \\
\text { averaged }\end{array}$ & $\begin{array}{l}\text { Allowable } \\
\text { per cent } \\
\text { variation } \\
\text { from } \\
\text { guaran- } \\
\text { teed life }\end{array}$ & $\begin{array}{l}\text { Number of lamps } \\
\text { averaged }\end{array}$ & $\begin{array}{l}\text { Allowable } \\
\text { per cent } \\
\text { variation } \\
\text { from } \\
\text { guaran- } \\
\text { teed life }\end{array}$ & $\begin{array}{l}\text { Number of lamps } \\
\text { averaged }\end{array}$ & $\begin{array}{l}\text { Allowable } \\
\text { per cent } \\
\text { variation } \\
\text { from } \\
\text { guaran- } \\
\text { teed life }\end{array}$ \\
\hline 250 and above. & 5 & $24-20 \ldots \ldots$ & 12 & $9 .$. & 19 \\
\hline $249-100 \ldots \ldots \ldots$. & 6 & $19-18 \ldots \ldots$. & 13 & $8 \ldots$ & 20 \\
\hline $99-55 \ldots . . . . . . . .$. & i & $17-16 \ldots \ldots$. & 14 & $7 \ldots$ & 21 \\
\hline $54-45 \ldots \ldots \ldots \ldots$ & 8 & $15-14 \ldots \ldots \ldots$ & 15 & 6.................. & 23 \\
\hline $44-35 \ldots \ldots \ldots \ldots$. & 9 & $13-12 \ldots \ldots \ldots \ldots \ldots$ & 16 & $5 \ldots \ldots \ldots \ldots \ldots$ & 25 \\
\hline $34-30 . \ldots \ldots \ldots$ & 10 & $11 \ldots \ldots \ldots$ & 17 & & \\
\hline $29-25 \ldots \ldots \ldots \ldots \ldots$ & 11 & $10 \ldots \ldots$ & 18 & & \\
\hline
\end{tabular}

$a$ On account of the natural and inherent variations in individual lamp performance, the average test results of a small number of test samples can not be depended upon to indicate exactly the average for the larger quantity from which the test samples were selected. The tables of allowable variations are devised in accordance with the observed accuracy of lamp-testing methods and the observed variations in lamp performance.

(j) Measurement of Lumens.-Life-test lamps shall be measured for lumens and amperes (or volts) at their labeled volts (or amperes) at reasonable intervals during the test.

(k) Determination of Lumen Maintenance.-The measure of lumen maintenance for an individual lamp shall be its mean lumens throughout the test, expressed as a percentage of its initial lumens.

The measure of lumen maintenance for a group of lamps shall be the mean lumens in per cent of average initial lumens and shall be determined by averaging the above percentages for the individual lamps, the percentage for each individual lamp being weighted in proportion to the life of the lamp. A simple and practical method of determining the desired mean lumens in per cent of average initial lumens for a group of lamps is to average, with equal weight, all readings on individual lamps representing (i. e., taken at the mid-points of) successive equal test intervals. A sufficient degree of accuracy will be obtained if readings are taken on the surviving individual lamps at times corresponding to 20,60 , and Ioo per cent of the life criterion and thereafter, at succeeding intervals equal to 40 per cent of the life criterion.

(l) Guaranteed Lumen Maintenance.-The guaranteed lumen maintenance of a group of lamps is expressed by the mean lumens in per cent of average initial lumens specified in the Standard Schedules of Commercial Ratings, except as modified by paragraph $(m)$. 
(m) Rejection for Failure to Meet Guaranteed Lumen Maintenance.-When tested in accordance with the foregoing test specifications, any group of lamps may be rejected, provided such group is represented on life performance test by at least five lamps, and provided the mean lumens in per cent of average initial lumens, as above derived, falls below the per cent specified in the Standard Schedules of Commercial Ratings by more than the tolerance specified below for the number of lamps tested.

Lumen Maintenance Tolerances $a$

\begin{tabular}{|c|c|c|c|}
\hline Number of lamps tested & $\begin{array}{l}\text { Allow- } \\
\text { able vari- } \\
\text { ation in } \\
\text { per cent } \\
\text { mean } \\
\text { lumens } \\
\text { of average } \\
\text { initial } \\
\text { lumens }\end{array}$ & Number of lamps tested & $\begin{array}{l}\text { Allow - } \\
\text { able vari- } \\
\text { ation in } \\
\text { per cent } \\
\text { mean } \\
\text { lumens } \\
\text { of average } \\
\text { initial } \\
\text { lumens }\end{array}$ \\
\hline 100 and above............ & 1 & $24-10 . \ldots$ & 3 \\
\hline $99-25 \ldots \ldots \ldots \ldots \ldots \ldots \ldots \ldots \ldots \ldots \ldots$ & 2 & $9-5 \ldots \ldots$. & 4 \\
\hline
\end{tabular}

$a$ On account of the natural and inherent variations in individual lamp performance, the average test results of a small number of test samples can not be depended upon to indicate exactly the average for the larger quantity from which the test samples were selected. The tables of allowable variations are devised in accordance with the observed accuracy of lamp-testing methods and the observed variations in lamp performance.

III. TABLES OF TOLERANCES AND CRITERIA

Vacuum Tungsten Filament Lamps for 110, 115, and 120 Volt Multiple Circuits

\begin{tabular}{|c|c|c|c|c|c|c|}
\hline \multicolumn{2}{|c|}{ Lamp } & \multicolumn{2}{|c|}{$\begin{array}{l}\text { Initial rating toler- } \\
\text { ances at rated } \\
\text { voltage }\end{array}$} & \multirow{2}{*}{$\begin{array}{c}\text { Standard } \\
\text { initial } \\
\text { lumens } \\
\text { per watt } \\
\text { for test }\end{array}$} & \multicolumn{2}{|c|}{ Life criteria } \\
\hline Watts & Bulb & $\begin{array}{l}\text { Iumens } \\
\text { per watt }\end{array}$ & $\begin{array}{l}\text { Total } \\
\text { watts }\end{array}$ & & $\begin{array}{l}\text { Mean } \\
\text { lumens } \\
\text { per watt }\end{array}$ & $\begin{array}{l}\text { Hours } \\
\text { at mean } \\
\text { lumens } \\
\text { per watt }\end{array}$ \\
\hline $10 \ldots \ldots \ldots \ldots$ & 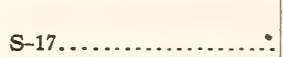 & $\begin{array}{r}\text { Per cent } \\
8\end{array}$ & $\begin{array}{r}\text { Per cent } \\
10\end{array}$ & 8.8 & 8.3 & 500 \\
\hline $15 \ldots \ldots \ldots \ldots$ & s-17........................ & 6 & 8 & 9.4 & 8.8 & 500 \\
\hline $25 \ldots \ldots \ldots$ & s-17.................. & 6 & 8 & 10.3 & 9.3 & 500 \\
\hline $40 \ldots \ldots \ldots \ldots$ & 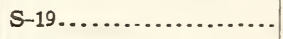 & 6 & 8 & 11.1 & 9.9 & 500 \\
\hline $50 \ldots \ldots \ldots \ldots \ldots \ldots$ & 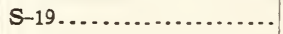 & 6 & 8 & 11.3 & 9.8 & 500 \\
\hline 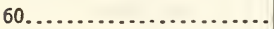 & 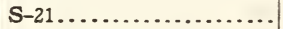 & 6 & 8 & 11.6 & 9.8 & 500 \\
\hline
\end{tabular}


III. TABLES OF TOLERANCES AND CRITERIA-Continued.

Gas-Filled Tungsten Filament Lamps for 110, 115, and 120 Volt Multiple Circuits

\begin{tabular}{|c|c|c|c|c|c|c|}
\hline \multicolumn{2}{|c|}{ Lamp } & \multicolumn{2}{|c|}{$\begin{array}{l}\text { Initial rating toler- } \\
\text { ances at rated } \\
\text { voltage }\end{array}$} & \multirow{2}{*}{$\begin{array}{c}\text { Standard } \\
\text { initial } \\
\text { lumens } \\
\text { per watt } \\
\text { for test }\end{array}$} & \multicolumn{2}{|c|}{$\begin{array}{l}\text { Life criteria } \\
\text { (for tip-down } \\
\text { burning) }\end{array}$} \\
\hline Watts & Bulb & $\begin{array}{l}\text { Lumens } \\
\text { per watt }\end{array}$ & $\begin{array}{l}\text { Total } \\
\text { watts }\end{array}$ & & $\begin{array}{l}\text { Mean } \\
\text { lumens } \\
\text { per watt }\end{array}$ & $\begin{array}{l}\text { Hours } \\
\text { at mean } \\
\text { lumens } \\
\text { per watt }\end{array}$ \\
\hline $75 \ldots \ldots$ & PS-22........ & $\begin{array}{r}\text { Per cent } \\
15\end{array}$ & $\begin{array}{r}\text { Per cent } \\
18\end{array}$ & 12.8 & 11.1 & 500 \\
\hline $100 \ldots$ & PS-25...... & 12 & 18 & 14.4 & 12.1 & 500 \\
\hline $150 \ldots$ & PS-25............ & 12 & 15 & 15.8 & 13.3 & 500 \\
\hline $200 \ldots$ & PS-30.......... & 12 & 15 & 17.7 & 14.8 & 500 \\
\hline $300 \ldots$ & PS-35.......... & 12 & 15 & 18.6 & 15.7 & 500 \\
\hline $500 \ldots \ldots \ldots \ldots . . . .$. & PS-40......... & 12 & 12 & 19.9 & 16.9 & 500 \\
\hline $750 \ldots \ldots \ldots \ldots$ & PS-52......... & 12 & 12 & 21.4 & 18.2 & 500 \\
\hline $1000 \ldots \ldots \ldots$. & PS-52.......... & 12 & 12 & 22.4 & 18.7 & 500 \\
\hline
\end{tabular}

Vacuum Tungsten Filament Lamps for 220, 230, 240, and 250 Volt Multiple Circuits

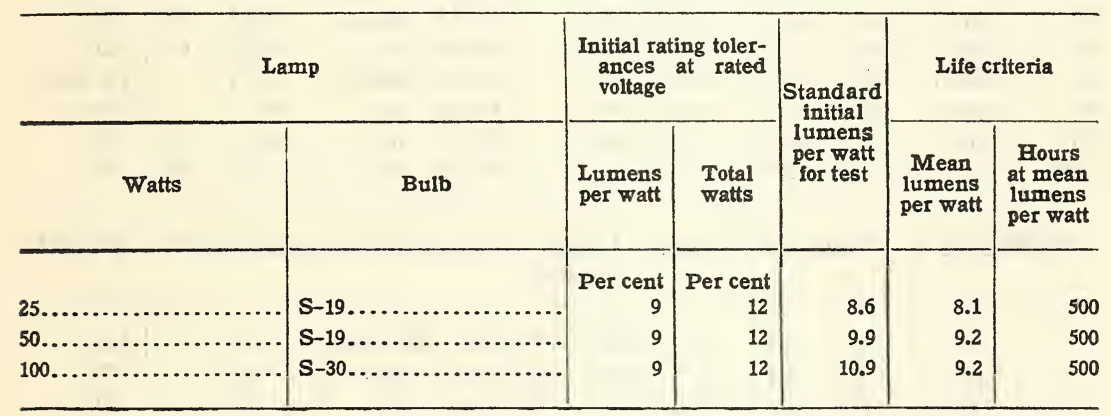




\section{STANDARD SCHEDULES OF COMMERCIAL RATINGS}

SCHEDULE 1.-Tungsten Filament Lamps for 110, 115, and 120 Volt Multiple Service

VACUUM LAMPS

\begin{tabular}{|c|c|c|c|c|c|c|c|c|c|c|c|}
\hline Watts & $\begin{array}{l}\text { Rated } \\
\text { initial } \\
\text { lumens }\end{array}$ & $\begin{array}{l}\text { Mean } \\
\text { lumens } \\
\text { per cent } \\
\text { of aver- } \\
\text { age } \\
\text { initial } \\
\text { lumens }\end{array}$ & $\begin{array}{c}\text { Rated } \\
\text { initial } \\
\text { lumens } \\
\text { per } \\
\text { watt }\end{array}$ & $\begin{array}{l}\text { Mean } \\
\text { lumens } \\
\text { per } \\
\text { watt }\end{array}$ & $\begin{array}{l}\text { Hours } \\
\text { life }\end{array}$ & $\begin{array}{l}\text { Spher. } \\
\text { reduc- } \\
\text { tion } \\
\text { factor }\end{array}$ & Bulb & $\begin{array}{c}\text { Screw } \\
\text { base }\end{array}$ & $\begin{array}{l}\text { Maxi- } \\
\text { mum } \\
\text { overall } \\
\text { length }\end{array}$ & $\begin{array}{l}\text { Light } \\
\text { center } \\
\text { length }\end{array}$ & $\begin{array}{l}\text { Position of } \\
\text { burning }\end{array}$ \\
\hline $10 \ldots$. & 78 & 90 & 7.8 & 7.4 & 1,000 & 0.77 & S-17 & Medium. & $\begin{array}{r}\text { Inches } \\
47 / 8\end{array}$ & $\begin{array}{c}\text { Inches } \\
\ldots . . . .\end{array}$ & Any \\
\hline $15 \ldots \ldots$ & 127 & 88 & 8.5 & 8.0 & 1,000 & .78 & S-17 & ...do...... & $47 / 8$ & & Do \\
\hline $25 \ldots$. & 232 & 86 & 9.3 & 8.4 & 1,000 & .78 & S-17 & ...do...... & $47 / 8$ & ....... & Do \\
\hline $40 \ldots$. & 396 & 85 & 9.9 & 8.8 & 1,000 & .78 & S-19 & ...do...... & $53 / 8$ & ....... & Do \\
\hline $50 \ldots$. & 495 & 83 & 9.9 & 8.6 & 1,000 & .78 & S-19 & ...do...... & $53 / 8$ & ....... & Do \\
\hline $60 \ldots$. & 606 & 82 & 10.1 & 8.5 & 1,000 & .79 & S-21 & ...do...... & $51 / 2$ & ........ & Do \\
\hline
\end{tabular}

GAS-FILIED LAMPS

\begin{tabular}{|c|c|c|c|c|c|c|c|c|c|c|c|}
\hline $75 \ldots \ldots$ & 862 & 85 & 11.5 & 10.0 & 1,000 & ...... & PS-22 & Medium. & $61 / 8$ & $4 \frac{5}{16}$ & Any \\
\hline $100 \ldots$ & 1,260 & 82 & 12.6 & 10.6 & 1,000 & $\ldots \ldots$ & PS-25 & ...do....... & $71 / 8$ & $5 \frac{5}{16}$ & Do \\
\hline $150 \ldots$. & 2,070 & 82 & 13.8 & 11.6 & 1,000 & & PS-25 & ...do...... & $71 / 8$ & $5 \frac{3}{16}$ & Do \\
\hline $200 \ldots$. & 3,100 & 82 & 15.5 & 13.0 & 1,000 & & PS-30 & ...do...... & $83 / 8$ & 6 & Do \\
\hline $300 \ldots$ & 4,890 & 82 & 16.3 & 13.8 & 1,000 & & PS-35 & Mogul... & $93 / 4$ & 7 & Tip down \\
\hline $500 \ldots$ & 8,700 & 82 & 17.4 & 14.8 & 1,000 & & $P S-40$ & ...do...... & 10 & 7 & Do \\
\hline $750 \ldots$ & 14,020 & 82 & 18.7 & 15.9 & 1,000 & & PS-52 & ...do...... & $133 / 8$ & $91 / 2$ & Do \\
\hline $1,000 \ldots$ & 19,600 & 82 & 19.6 & 16.4 & 1,000 & & PS-52 & ...do...... & $133 / 8$ & $91 / 2$ & Do \\
\hline
\end{tabular}

SCHEDULE 2.-Tungsten Filament Lamps for 220, 230, 240, and 250 Volt Multiple Service

\begin{tabular}{|c|c|c|c|c|c|c|c|c|c|c|c|}
\hline $25 \ldots$. & 190 & 92 & 7.6 & 7.2 & 1,000 & 0.79 & S-19 & Medium. & $53 / 8$ & $\cdots$ & Any \\
\hline $50 \ldots$. & 445 & 88 & 8.9 & 8.3 & 1,000 & .79 & S-19 & ... do...... & $53 / 8$ & & Do \\
\hline $100 \ldots$ & 990 & 86 & 9.9 & 8.4 & 1,000 & .79 & $S-30$ & ...do....... & $77 / 8$ & …...... & Do \\
\hline
\end{tabular}

\section{PART 2.-STANDARD SPECIFICATIONS FOR LARGE CARBON FILAMENT INCANDESCENT ELECTRIC LAMPS}

\section{GENERAL SPECIFICATIONS}

Subsections I, 2, and 3 of the General Specifications for large tungsten filament lamps, entitled respectively, General Conditions, Definitions and Standards, and Return of Rejected Lamps, shall apply likewise to carbon filament lamps. (See pp. 7-9.)

\section{CANCELLATION OF CONTRACT}

A contract for lamps furnished under these specifications may be canceled in the event that the average actual test-life values determined up to any given time are less than 90 per cent of the test-life values given in Section III of these specifications. 


\section{TEST SPECIFICATIONS.}

\section{MECHANICAL AND PHYSICAL INSPECTION TEST}

All provisions of the corresponding section of the specifications for large tungsten filament lamps shall apply likewise to carbon filament lamps, except that subhead $(j)$ shall not apply.

\section{INITIAL RATING TEST}

Specifications for large tungsten filament lamps shall apply to carbon lamps, except that subhead (d) shall not apply.

\section{LIFE PERFORMANCE TEST}

(a) Selection and Test Quantity of Lamps for Life Performance Test.-The specifications for large tungsten filament lamps shall apply likewise to carbon filament lamps.

(b) Life-Test Voltages. - Life-test lamps shall be operated on the life-test rack at voltages (or currents) corresponding to an initial rating of 3.70 watts per spherical candle or to any test watts per spherical candle agreed upon. Operation at approximately the voltages indicated is sanctioned, provided proper life corrections are made.

(c) Voltage regulation.-Accurate recording voltmeter records shall be obtained during the life test on lamps to show the variation of the voltage on the circuit.

Variations of voltage are not to exceed one-quarter of I per cent above and below the test voltage.

(d) Candlepower Measurements.-During life test carbon lamps shall be read for candlepower and current at the test voltage at approximately 50 hours, and at least every 100 hours thereafter until the candlepower shall have fallen 20 per cent below the initial candlepower, or until the lamp breaks, if within that period.

(e) Test Life.-The number of hours each lamp burns until the candlepower has decreased to 80 per cent of its initial value, or until the lamp breaks, if within that period, is known as the test life.

Lamps broken in handling or when current is not on them shall not be counted to reduce the average lamp life.

In case any life-test lamps (and their duplicates) are broken or damaged before the test is completed, the average life of all lamps of the same size and voltage range tested under the same contract shall be assigned to the package or group of packages represented by such broken or damaged life-test lamp. 
(f) Rejection for Deficient Life.-Any group of the lamps initially inspected may be rejected, provided such group is represented on life test by at least five lamps, if the average test-life value is less than 90 per cent of the test-life value specified in Section III of these specifications.

\section{TABLES OF REQUIREMENTS AND TOLERANCES}

Clear, Oval-Anchored, Regular Carbon Lamps for 110 to 125 Volt Multiple Circuits

\begin{tabular}{|c|c|c|c|c|c|c|}
\hline \multirow[b]{2}{*}{ Size of lamp in watts } & \multirow[b]{2}{*}{$\begin{array}{l}\text { Initial } \\
\text { mean } \\
\text { hori- } \\
\text { zontal } \\
\text { candle- } \\
\text { power at } \\
\text { rated } \\
\text { voltage }\end{array}$} & \multicolumn{4}{|c|}{$\begin{array}{l}\text { Initial rating tolerances at rated } \\
\text { voltage }\end{array}$} & \multirow{2}{*}{$\begin{array}{l}\text { Average } \\
\text { perform- } \\
\text { ance: } \\
\text { Test life } \\
\text { in hours } \\
\text { to } 20 \text { per } \\
\text { cent drop } \\
\text { in can- } \\
\text { dlepower } \\
\text { at } 3.70 \\
\text { watts per } \\
\text { spherical } \\
\text { candle }\end{array}$} \\
\hline & & $\begin{array}{l}\text { Indi- } \\
\text { vidual } \\
\text { candle- } \\
\text { power }\end{array}$ & $\begin{array}{l}\text { Mean } \\
\text { candle- } \\
\text { power }\end{array}$ & $\begin{array}{l}\text { Indi- } \\
\text { vidual } \\
\text { watts }\end{array}$ & $\begin{array}{l}\text { Mean } \\
\text { watts }\end{array}$ & \\
\hline 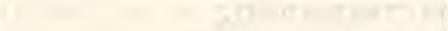 & & Per cent & Per cent & Per cent & Per cent & \\
\hline $20 \ldots$ & 4.8 & 20 & 12.5 & 12 & 6. & 300 \\
\hline $25 \ldots \ldots$. & 8.1 & 20 & 12.5 & 10 & 5 & 300 \\
\hline $30 . .$. & 9.3 & 20 & 12.5 & 10 & 5 & 350 \\
\hline $50 \ldots \ldots . .$. & 16.8 & 7.5 & 2.5 & 5.5 & 2.5 & 450 \\
\hline $60 \ldots \ldots \ldots$ & 20.2 & 7.5 & 2.5 & 5.5 & 2.5 & 420 \\
\hline
\end{tabular}

Clear, Double Oval-Anchored Regular Carbon Lamps for 220 to 250 Volt Multiple Circuits

\begin{tabular}{r|r|r|r|r|r|r}
\hline $35 \ldots \ldots \ldots \ldots \ldots \ldots \ldots \ldots \ldots \ldots \ldots \ldots \ldots \ldots \ldots$ & 8.0 & 25 & 12.5 & 15 & 7.5 & 120 \\
$60 \ldots \ldots \ldots \ldots \ldots \ldots \ldots \ldots \ldots \ldots \ldots \ldots \ldots$ & 16.3 & 15 & 7.5 & 12 & 6 & 160 \\
\hline
\end{tabular}

The average spherical reduction factor for all these lamps is 82.5 per cent.

It is recommended that every effort be made to avoid ordering lamps of actual rated voltages IIO, II I, I2I to I25, inclusive, and 220. For such lamps the initial rating tolerances for the respective sizes shall be double those given in the above table.

For lamps of rated voltages between 120 and 125 , inclusive, the test-life values shall be 95 per cent of those given in the table above.

Lamps in this schedule should burn on life test in one horizontal position at a voltage corresponding to an initial specific consumption of 3.70 watts per spherical candle without excessive drooping of the filament.

The labels on the lamps shall show the nominal total watts and voltage. 